\title{
On the Cultural Confidence Guided by Marxism Belief
}

\author{
Zhao Meng \\ Wuhan Huaxia University of Technology, Wuhan 430223, China \\ zhaomengwh@126.com
}

Keywords: cultural confidence; Marxism; socialism with Chinese characteristics; three confidence

\begin{abstract}
It is necessary to firmly believe in the confidence and system in the road of socialism with Chinese characteristics. Cultural confidence is a more fundamental, deeper and more enduring power, a more fundamental, broader, and deeper self-confidence. Guided by the Marxist socialist advanced culture, the scientific connotation of cultural self-confidence can enhance cultural confidence and firm faith in Marxism to correctly understand the relationship between Marxism and Chinese excellent traditional culture.
\end{abstract}

\section{Introduction}

In the past 40 years since the reform and opening up, China's economy has been developing with each passing day[1]. However, compared with the rapid development of economic prosperity, cultural development has shown a tendency of being slow and even lagging behind. Culture is an important source of national cohesion and creativity, and also an important factor in the competition of comprehensive national strength. With the continuous development of times and society, the importance of culture becomes more and more prominent. However, the development of culture cannot be separated from the confidence of native culture. Cultural confidence is a nation, a nation, a political party's full affirmation of its own cultural values, and a firm belief in the vitality of its own culture. Cultural confidence is a major problem that needs to be solved after China has made great economic achievements and social progress.

\section{Grasp the Significance of Cultural Confidence}

The reason why the Chinese nation stands tall in the world is because we have a strong cultural heritage, which is an important driving force for China's political, economic and cultural development[2]. Cultural confidence is not only an important indicator of the strength and weakness of a country, but also an important aspect of national quality. Therefore, it is of great theoretical and practical significance to enhance the cultural confidence and the development and progress of Chinese society.

\subsection{It is the foundation and source of road confidence, theoretical confidence and system confidence.}

First of all, cultural confidence is the foundation and source of road confidence[3]. Cultural confidence is the confidence that inherits from tradition, is rooted in people's heart, and provides abundant nourishment for road confidence. Cultural confidence is the latest theoretical achievement of the sinicization of marxism, and the confidence of culture includes the confidence of marxism. Under the guidance of marxism, China has embarked on a socialist road with Chinese characteristics, which is the result of unswerving belief in marxism. China has always adhered to the theoretical guidance of marxism, because it is proved by historical practice to be scientific, rational and valuable. Historical practice proves that it is the right choice of our country to insist on marxism. Therefore, enhancing the self-confidence of marxism is the foundation and source of the road confidence.

Secondly, cultural confidence is the foundation and source of theoretical confidence[4]. China's excellent traditional culture, marxist theory and socialism with Chinese characteristics are the three 
main sources. We say the theory of socialism with Chinese characteristics is the theory of "characteristics", the reason is that it is in the stick to marxist theory on the basis of close ties to the development of China's primary stage of socialism and the theory put forward by achievement, is according to the development status of China in different periods of the theory, principles and policies, accords with the practice of China's development. Confidence in these theories stems from a belief in Chinese culture.

Finally, cultural confidence is the foundation and source of system confidence. The system of socialism with Chinese characteristics is a new system established on the basis of reforming the old system. It is the result of the transformation of the traditional system modernization and the product of the sinicization of marxism. The unique cultural tradition, the historical destiny of the ups and downs, the severe and complex basic national conditions have created the basic system of our society. For thousands of years, China's outstanding traditional culture has been inspiring every generation of Chinese people to strive for self-improvement and perseverance. They have been born again and again in times of adversity, and they have gone from darkness to light. This powerful force of cultural confidence is an important foundation for the perfection of the socialist system with Chinese characteristics.

Western countries, all in the name of the cultural exchange to input new liberal thought in our country, the opportunity to penetrate and western constitutional democracy thought of "universal value", in an attempt to encourage the people against socialism and the mainstream ideology of marxism. Enhance cultural self-confidence, will raise awareness of our cultural identity and self-confidence, to recognize the essence of new liberalism, encourage people to view of, from the view of rational development of western culture. To enhance their own cultural confidence is also to some extent to resist the invasion of neoliberalism.

Second, it is helpful to resist the invasion of historical nihilism[5]. Historical nihilism advocates the whole westernization, attempts to erase our revolutionary struggle history, negates the achievements of socialist development, distorts historical facts. Faced with the challenge of historical nihilism, people must firmly believe in culture and give a strong response. China is a country with a long history, and the confidence of our traditional culture is the cornerstone of the firm cultural confidence. The cultural confidence of our country originates from the excellent traditional culture, revolutionary culture and advanced socialist culture, which are the cells and genes of China's construction of cultural power. Facts have proved that practice is the sole criterion for testing truth. It is the objective law of the historical and cultural development to establish the cultural confidence, which is the key to the correct interpretation of history, and can make people realize the wrong essence of historical nihilism. Therefore, it is the most powerful weapon against historical nihilism to firmly believe in culture and adhere to the mainstream ideology of marxism.

\subsection{It is an important way to promote our traditional culture to the world.}

For cultural self-confidence not only embodies in inheriting Chinese excellent traditional culture, more important is to this national culture to the world stage[6], and culture is to promote the Chinese excellent traditional culture to the world's important way. Once appeared on attitude towards the culture of Chinese americans "inferiority ziqi" and "arrogance" two kinds of extreme positions, the two extreme position is wrong, will be a negative impact on cultural construction. History suggests that a country only attach importance to the nation's cultural development, our national culture to maintain a high degree of identity and self-confidence, to make their people get rid of the psychological "inferiority ziqi, ambitious, have the courage to stand on the world stage, spreading Chinese excellent traditional culture, to the peoples of the world will carry forward the culture of the Chinese nation.

In today's world, with the increasing competition of cultural soft power, cultural exchanges, exchanges and exchanges between different countries are more frequent than ever before. In such a competitive international environment, a developing country like China, if you want to say, it is necessary to strengthen cultural soft power, and enhance the cultural soft power an important way to spread traditional Chinese culture to the world stage. In view of the current development environment, 
the competition of comprehensive national strength is increasingly fierce, and the importance of culture to all countries is getting deeper and deeper. Enhancing cultural confidence is conducive to enhancing the soft power of national culture and giving the country, enterprises and individuals confidence to show the outstanding traditional culture of the Chinese nation to the people of the world.

In the long historical development process of the Chinese nation created a special cultural system, after the baptism of history and elimination, only the culture of the Chinese nation is continues today, shows the superiority of Chinese national culture and strong sex. With the growing of China's comprehensive national strength, the "China craze" has become the hottest topic nowadays, learning Chinese culture become a trendy, foreign students and our country is trying to its excellent traditional culture spread to the world. In recent years, China has established many Confucius institutes abroad so that foreign friends can learn and understand Chinese culture more easily. The establishment of Confucius institutes also promoted the cultural exchanges between China and other countries in the world, all of which originated from China's high confidence in our national culture.

\subsection{It is helpful to improve our voice in the world.}

Strengthening cultural confidence will be the main direction of cultural development in our country in the future, on the one hand, it is helpful to improve our country's cultural soft power, raise the context of Chinese culture in the world make their sounds right, get a seat for himself; On the other hand, in the process of globalization, the enhancement of cultural confidence is conducive to the promotion of the overall national strength of the whole country, thus enhancing the voice and initiative of our country in the international community. Enhancing cultural self-confidence includes enhancing the confidence of traditional cultural spirit, Chinese brand and Chinese story, and improving their confidence in them will help to improve China's voice in the world.

Firstly, the confidence of Chinese traditional culture spirit is the foundation for our country to strive for international discourse power. The Chinese culture has a long and profound history, which has nurtured many excellent traditional cultural spirits since ancient times, including the unity of heaven and man, the virtues of virtue, the unremitting self-improvement, and the hardships of hardships and hardships. Firm confidence of the Chinese traditional culture spirit, fully demonstrate the unique charm of Chinese culture to the peoples of the world and rich heritage, Chinese value ideas, for the people of the world to understand China's culture, recognized the culture of our country, accept the value concept and value pursuit, to provide powerful backing for more international discourse in China.

Secondly, the confidence of Chinese culture brand is the strength of our country to strive for international discourse power. With the intensification of international competitiveness, all countries are making great efforts to strengthen their cultural soft power and create their own cultural brands. The same is true in our country, in the face of strong technology strength, under the pressure of the western brand maintain a high level of confidence about Chinese culture, with Chinese characteristics will make for the development of cultural undertakings and cultural industries, to promote Chinese culture and world cultural market, the development trend of the accurate understanding of the international cultural market, makes the "made in China" into the market of world famous brand, enhance brand influence and creativity in China. The confidence brought by this cultural brand will enhance China's influence in the world, and thus give China more international say.

Finally, confidence in the Chinese story is an important guarantee for our country to strive for international discourse power. The Chinese nation has a glorious history tradition, has a wealth of cultural achievements, behind this is the Chinese people of all ethnic groups throughout your generations, and constantly strive to continuously improve, passed down generation after generation of color with a history of Chinese story, is the wealth of our firm cultural confidence and capital. Keep self-confidence of traditional stories of Chinese history, we have the confidence, have the courage to tell the people all over the world with a culture with Chinese characteristics, to show the unique cultural charm and background in our country, thus get recognition and study of the international community, to promote national cultural soft power and international influence of the country, it is 
very important to our country get more international voice.

\section{Ways to Enhance Cultural Confidence}

With the continuous enhancement of China's economic strength, the importance of cultural forces in competition has become more and more prominent, and how to enhance our cultural confidence is one of the major tasks facing our country today. Cultural construction in our country development lag, the continuous influx of western various social conditions, explore the basic path to enhance the cultural confidence in the development of culture, personal qualities of ascension, all has the vital significance.

\subsection{Vigorously promote the core values of China's outstanding traditional culture and socialist culture}

The excellent traditional culture can promote the continuation of Chinese culture, which can promote the inheritance of the national spirit, while the core value idea is the core force that can bring a country or nation together. The enhancement of cultural confidence requires not only the traditional culture, but also the role of the core values of culture, and it should be passed down from generation to generation. To carry forward China's excellent traditional culture and actively practice socialist core values can enhance people's cultural identity and enhance cultural confidence.

First of all, we should vigorously promote the excellent traditional culture and enhance our sense of identity with the outstanding traditional Chinese culture. It is the responsibility and obligation of every Chinese child to enhance the people's sense of identity of the outstanding traditional culture and enhance the national pride, confidence and pride of the people. Promote cultural identity are the main group of young people, and enhance their sense of identity, need to play to the spread of the modern new media function, let more young people through micro letter, weibo, live close to the platform of their lives to get to know our country outstanding traditional culture, so as to deepen their understanding of the traditional culture and to understand. In addition, corporate culture is an important way to spread traditional culture to young people. An enterprise wants to do big, do strong, corporate culture is the essential factor, younger workers are more and more of the modern enterprise, then the excellent traditional culture into the enterprise culture, can better enhance young people's cultural identity.

Secondly, the Chinese excellent traditional culture and modern culture are integrated. Have excellent traditional culture is the basis and premise of cultural self-confidence, is indispensable to develop modern culture important source and the basic conditions, is also the eternal youth and vitality of the Chinese nation precious wealth. The development of modern culture, whether from the cultural content or the form, requires the excellent traditional culture of the Chinese nation, including the national spirit, as the foundation and premise. On the content, the traditional culture should be combined with the characteristics of The Times to create a modern socialist culture with Chinese characteristics. Form, adopt various forms to fuse traditional culture with The Times characteristics, including building features restaurants, with national characteristics of modern clothing design, modern architecture, carry forward the concept of green travel, etc. Therefore, only by constantly updating the content of culture and enriching the form of cultural development, and keeping pace with The Times, can we better enhance cultural confidence.

\subsection{Actively develop cultural undertakings and cultural industries}

Cultural undertakings and cultural industries can't develop without cultural innovation, cultural innovation is on the basis of inheriting traditional culture, combining with the current situation of the development of contemporary culture and the needs of the people's spiritual culture, a culture of creation. To improve cultural development system in our country, on the basis of developing culture industry and public welfare undertakings, driving the innovation of the whole society people's enthusiasm, make more people into the process of the cultural industry to create, to strengthen people's cultural self-confidence. 
First, we need to deepen reform of the cultural system. At present, China's cultural construction is in the deep-water zone of reform and development, and the comprehensive deepening of reform is not only in the political and economic fields, but also in the cultural field. First, we should make scientific and rational plans to accurately grasp the pace and pace of cultural reform. The reform of the cultural system is a complex system project, and it must be carried out in an organized and planned way, starting from the point to the line, from the line to the surface, and fully spreading out. We should proceed actively and steadily, not in a hurry, in a hurry and in a disorderly pace. Second, we must be resolute in our attitude towards the reform of the cultural system. The conviction and determination to reform, overcome the fear, abandon the outdated mindset, keep pace with The Times, make a decision, and make comprehensive plans and plans. Third, the pace of cultural restructuring must be steady, steady and steady. In the face of all the complex difficulties and challenges in the society, the reform of the cultural system cannot affect the stability and development of the society. It must gradually advance in a smooth and orderly manner and proceed steadily. In this process, we should adhere to the principle of concrete analysis. Through continuous practice, summarize experiences and lessons, accumulate useful experience for the establishment of a perfect social cultural system and enhance cultural confidence.

We should deepen cultural system innovation. We must not only keep pace with The Times in our thinking, but also keep pace with The Times in the innovation of cultural system. First, promote institutional innovation of state-owned cultural enterprises. State-owned cultural enterprises are an important part of the development of market economy. In the current situation of economic development, it is the only way for state-owned cultural enterprises to become market subjects. To make state-owned cultural enterprises become the market main body, it is necessary to change in the past in the form of administration to promote its development, should actively play the role of market economy, the internal implementation of property rights reform of state-owned cultural enterprises, the sponsor system effectively combine with the manager system, realize the innovation of the system development. Second, enrich cultural products and establish a market for cultural factors. In a market economy, to realize the "flowers" in the field of economy, it is necessary to give all sorts of private enterprises and the non-public cultural enterprises to build a better form of economic development, completes the various propaganda work, make it get more ordinary people's support and understanding; Concept, value orientation has been the core of marxism and the core value orientation of our country is in line, and gradually got the masses of the people's support and recognition, has become an important support of cultural self-confidence; Method, want to always adhere to the materialist dialectics as the fundamental method of solving practical problems, use dialectical thinking to identify the Chinese traditional culture and foreign culture, and strive to do neither blind exclusion, again not careless absorption, further to strengthen cultural confidence to provide scientific theory source and the correct way.

Secondly, in the process of developing modern culture, we should integrate marxism with the development of contemporary culture. Integrating marxism into the development of modern culture is an important direction for the present and future development. It also represents the orientation of the advanced socialist culture. In the process of developing modern culture, we should adhere to the general direction of marxism, and do not deviate from it. Marxism as a mainstream ideology in our country, to be consistent with China's state of the cultural development, insist on seeking truth from facts and advancing with The Times, constantly enrich the content of the modern culture, to create both the era characteristics, and to have the traditional charm of modern culture, it to a certain extent, improve the socialist cultural identity and self-confidence in the people. Therefore, insisting on integrating marxism with Chinese modern culture can promote the improvement of our cultural confidence level.

\section{References}

[1] Carle A C, Weechmaldonado R, Ngometzger Q, et al. Evaluating Measurement Equivalence across Race and Ethnicity on the CAHPS ${ }^{\circledR}$ Cultural Competence Survey[J]. Medical Care, 2012, 
50(2):32-6.

[2] Ousmanova A. On the Ruins of Orthodox Marxism: Gender and Cultural Studies in Eastern Europe[J]. Studies in East European Thought, 2003, 55(1):37-50.

[3] Jamin J. Anders Breivik, « Cultural Marxism » and the blogosphere 1997 - 2012[J]. Theory Culture \& Society, 2013, 32(7-8):417-419.

[4] Chelminski P, Coulter R A. The Effects of Cultural Individualism and Self-Confidence on Propensity to Voice: From Theory to Measurement to Practice[J]. Journal of International Marketing, 2007, 15(4):94-118.

[5] Daenekindt S, Roose H. Cultural chameleons. Social mobility and cultural practices in the private and the public sphere[J]. Acta Sociologica, 2013, 56(4):309-324.

[6] Shi M. On the Values Dimension and Realistic Purpose of University Culture Responsibility[J]. Educational Research, 2014. 